\title{
DFFU på sociale medier
}

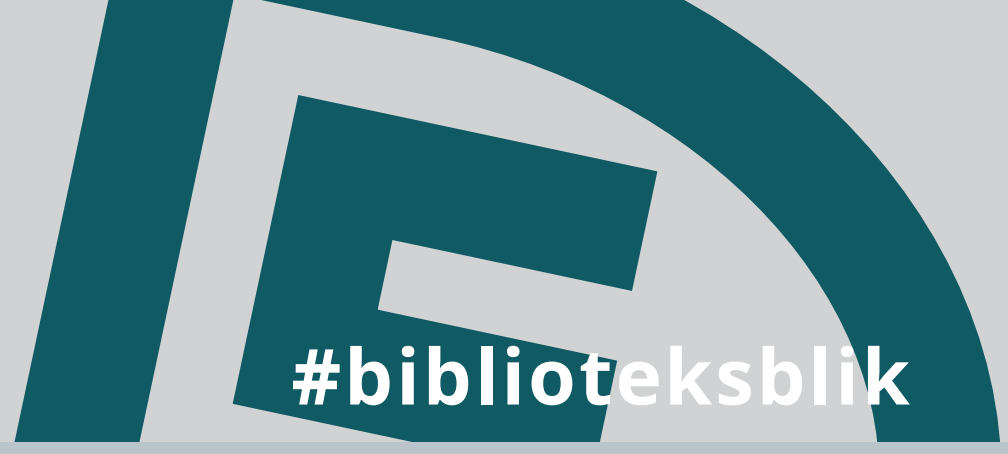

Vi samler billeder på instagram. Enten fra bibliotekerne eller fra private brugere.

Her er et par af redaktionens favoritter.
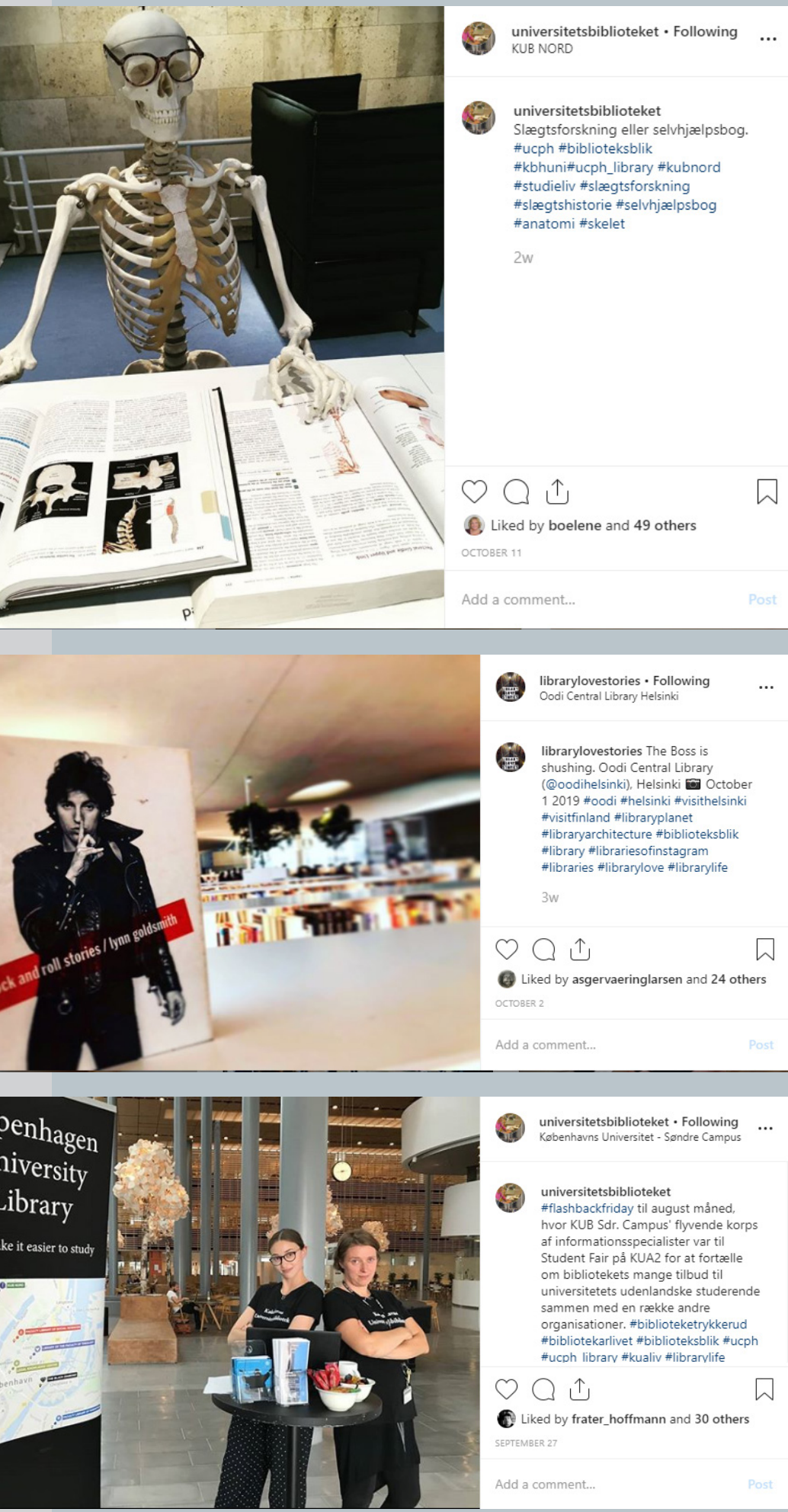
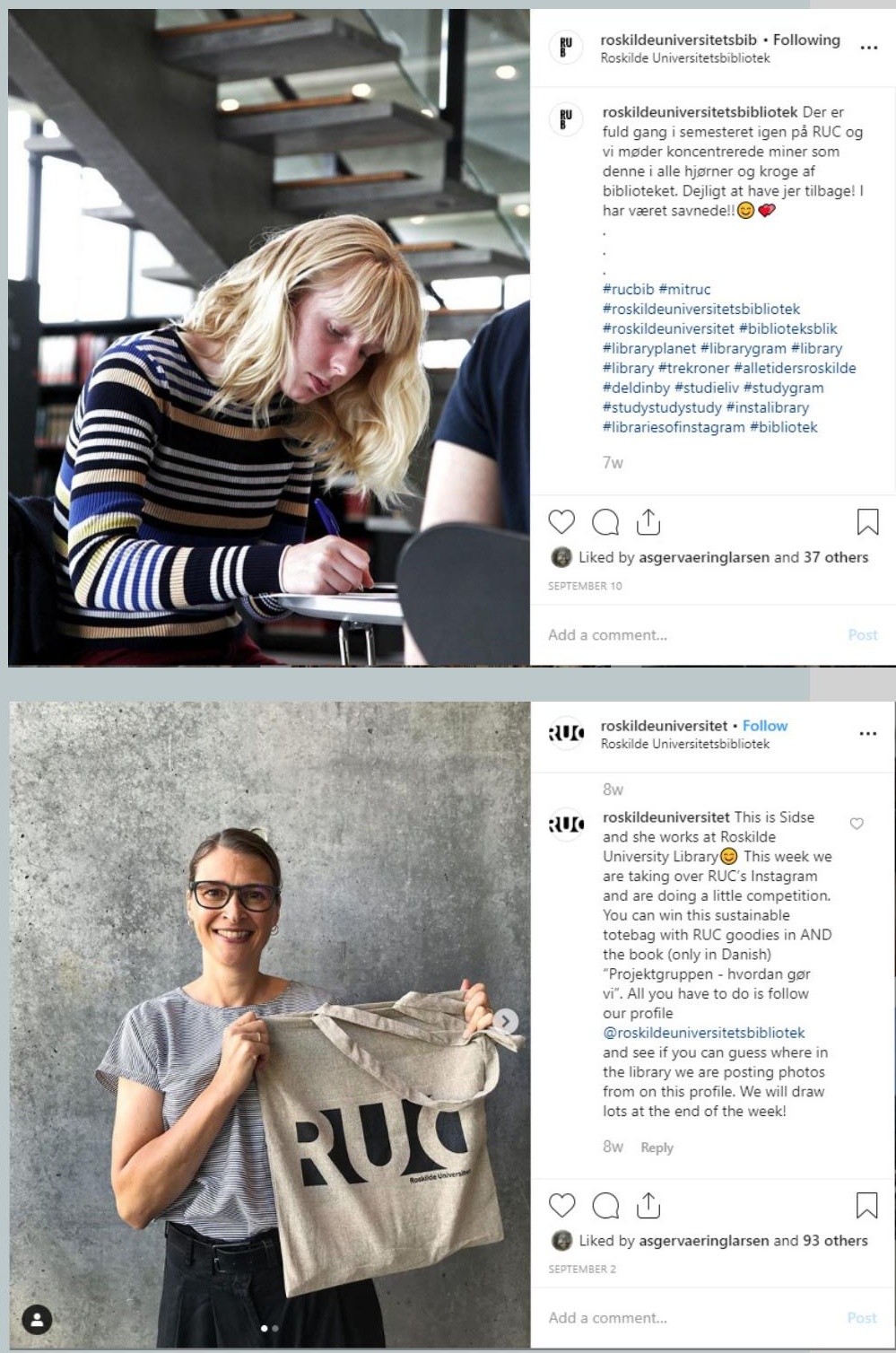

Brug \#Biblioteksblik - hvis du vil ses af os 